\title{
Antecedents of late life outcomes: the case of Israel
}

\author{
Sharon Shiovitz-Ezra ${ }^{1}$
}

Published online: 20 October 2016

(C) Springer-Verlag Berlin Heidelberg 2016

This special section presents five papers that examine different late-life outcomes such as quality of life (QoL), functional health, depression, and loneliness. All of the papers relate to the Israeli component of the Survey of Health, Ageing and Retirement in Europe (SHARE). In the SHARE project, multidisciplinary panel data were obtained in 20 European countries, including Israel, from approximately 123,000 respondents aged 50 and over across five waves of data collection (the sixth wave of data collection ended in November 2015). The SHARE data include extensive information on physical, cognitive, and mental health as well as on socioeconomic indicators and social and family networks (Malter and Börsch-Supan 2015). Israel joined SHARE in 2005, and most recently completed four waves of data collection. The papers in this special section used data from the first three waves of SHAREIsrael to investigate antecedents of conspicuous late life outcomes. The use of panel data has enabled the authors to address the dynamic rather than the static nature of the ageing process.

Ageing does not occur in a vacuum, of course, and cultural dimensions have a profound impact on it (Sokolovsky 2009). Israeli society, in particular, provides a complex socio-cultural-political background that should be taken into consideration when exploring age and ageing at the individual level. Despite its small population, Israel is defined as a deeply divided society with enormous internal

Responsible editor: H. Litwin

Sharon Shiovitz-Ezra

sharon.shiovitz@mail.huji.ac.il

1 Paul Baerwald School of Social Work and Social Welfare, The Hebrew University of Jerusalem, Jerusalem, Israel schisms based on ethnicity, religion, cultural background, attitudes towards modernity, political ideologies, and life style (Smooha 2010). The complex social structure of Israeli society includes several opposing groups: Jews/ Arabs, ultra-Orthodox/secular, Westernized/traditional, socialist/nationalist (Dowty 2004).Within the Jewish population, the term edah (community group) is commonly used to differentiate between Jewish groups based on their country of origin. Whereas most sociologists use the terms edah and ethnic groups interchangeably, others consider this to be misleading, and have suggested different terms such as "subculture" to delineate the division among Jewish groups (Ben-Rafael and Sharot 1991). In this regard, a well-known division is between Jews of AsianAfrican origin (Mizrahim) and Jews of European-American origin (Ashkenazim). Another division is based on religiosity: ultra-orthodox (Haredim), Orthodox, traditional, and secular Jews. In addition, there is a division between immigrants and non-immigrants (Horowitz 2003).

One of the largest immigrant groups in Israel originates from the Former Soviet Union (FSU). Following Cold War politics and the collapse of the Soviet Union, over 1.8 million Jews and their non-Jewish family members emigrated from the FSU (Cohen et al. 2011), more than half of which immigrated to Israel, in two waves. The first wave was between 1971 and 1974, and consisted of about 100,000 people. Most of them immigrated to Israel, and they were mainly Zionist, religious, and traditional. The second wave ${ }^{1}$ began in mid-1989 with a mass exodus of the Jewish minority. About 1,500,000 people left the FSU, and most of them immigrated to Israel (approximately 900,000 by October 2000). The relatively small number of the first

\footnotetext{
1 There was another migration of Jews from the FSU between 1975 and 1989, mostly to North America (Gitelman 2004).
} 
wave of new FSU immigrants (olim) eased that group's integration into Israeli society and the labor market. Moreover, as Zionists in orientation, they felt close to the Jewish tradition and culture, and they adopted the Israeli identity. These characteristics provide an explanation for their relatively easy and painless adjustment to Israel, as well as for their rapid assimilation into Israeli society (Gitelman 2004).

The massive influx of Soviet Jewish migration in the 1990 s, in contrast, was different from the earlier wave in many ways. It is argued, in this regard, that the push factors for emigration from the FSU were stronger than the pull factors for immigration to Israel (Gitelman 2004). Among the push factors was the emergence of an economic crisis in the FSU that threatened the welfare of the middle class, to which most of the Jewish population belonged. There was also an awakening of ethnic nationalism among the population of the FSU, which was accompanied by a rise in anti-Semitism and harassment of the Jewish minority. On the other hand, the main pull factor for immigration was the presence in Israel of relatives and friends who had already left the Soviet Union (Ben-Rafael et al. 2006; Remennick 2006). The immigrants in the second wave were much less Zionist in orientation than those who had preceded them, and they immigrated for pragmatic reasons. Among them were many non-Jewish relatives of Jews who were able to immigrate under the Israeli Law of Return. This massive wave of immigrants to Israel in the 1990s created a Russian language sub-culture with Russian-language entertainment venues, theaters, bookstores, libraries, and newspapers. In many respects they represented a major shift in Israeli society, from a "melting pot" to a more culturally pluralistic society characterized by ethnic diversity. Some might argue that this shift advanced "tribalization" and segmentation of Jewish society in Israel (Gitelman 2004). In that vein, Ben-Rafael et al. (1998) maintained that the immigrants from the FSU sought neither segregation nor integration in Israeli society. What they wanted was legitimacy for their cultural uniqueness, and integration as a secular group. Other scholars have argued that the new immigrants from the FSU will eventually be integrated into the Ashkenazi middle class in Israel (Kimmerling 1998; Smooha 1994). But Al-Haj (2002) has challenged this conventional approach, arguing that immigrants from the FSU are in the process of forming a distinct ethnic group. In his view, this is an instrumental adjustment strategy that reflects their desire to integrate into Israeli society from a position of strength rather than assimilate from a position of weakness.

The emergence of Russian culture in Israel might also be attributed to the enormous size of the second wave of immigrants. It might also relate to the fact that this wave was characterized largely by highly educated and skilled people. Despite the qualifications of the second wave of immigrants from the FSU, however, their economic absorption became very difficult within a very short time. The difficulties were reflected in a very high unemployment rate during the initial period after their arrival, (although there has been an increase in the employment rate over time). Currently, the unemployment rate among the migrants from the FSU is still slightly higher than the national average. However, immigrants over age 50, especially women in that age group, have experienced considerable difficulties in the labor market (Gitelman 2004). Unemployment is only one aspect of the problem. Another, no less important issue, is employment downgrading. Older immigrants are rarely employed in their field, or in positions comparable to those that they held in their country of origin. This is significant because work is much more than a means of subsistence; it represented status and social identity in Soviet society (Litwin and Leshem 2008).

A fourth, and perhaps the most pronounced division in Israeli society, is related to the Arab-Jewish schism. ArabIsraelis, who are also referred to as Palestinian citizens of Israel, constitute $20.7 \%$ of the total population $(1,720,300$ people; Central Bureau of Statistics (CBS) 2015a). About $75 \%$ are Muslim, $15 \%$ are Christian, and $9 \%$ are Druze (Sharkansky 2004). The Arab citizens of Israel have been referred to as an indigenous minority (or a "homeland minority") (Smooha 2010). Even though they constitute a relatively large share of the population, their social status is low and there is social inequality as well as disparities in power and prestige. In addition, Arab-Israelis are a distinct minority in terms of religion, language (Arabic) and lifestyle, which is much more traditional than that of the Jewish majority. Besides being an ethnic, religious, linguistic, and cultural minority, they are also a national minority as part of the Palestinian people and the Arab world (Smooha 2010). However, the most unique and complex situation is reflected in the definition of the Arab population of Israel as a "double periphery", or a "trapped minority" which has been marginalized by the Jewish majority as well as by the Palestinian national movement (Al-Haj 2004; Rabinowitz 2001). Their identity combines the component of Palestinian-Arab nationalism with the component of Israeli-citizenship. This complex identity simultaneously includes two hostile reference groups: the Jewish majority in Israel, and the Palestinian people. As mentioned, they have remained at the margins of both of these groups (Al-Haj 2004).

Formal policies towards the Arab population in Israel have been shaped by three main factors: the democratic character of the country; its Jewish-Zionist orientation; and the volatile security situation. The democratic character of Israel, which is evident, both at the local and national 
levels, has allowed Arab-Israelis to organize politically, and to be actively involved in advancing their status and rights. However, the framing of Israel as the state of the Jewish people has major implications for national priorities and allocation of resources. Moreover, the ongoing ArabIsraeli conflict has placed the Arab-Israeli population in a problematic position. They are perceived by many Jews as a "hostile minority" which poses a security risk (Al-Haj 2004). The definition of Israel as a Jewish and a democratic state has generated additional conflict and debate. Whereas some claim that Israel is an ethnic democracy (Smooha 1997), others have defined it as an ethnocracy (Yiftachel 2006), i.e., as a unique separate type of political regime that is neither democratic nor authoritarian, and that promotes a process of "ethnicizing" contested territories and power structures (Yiftachel and Ghanem 2004, p 648).

In any event, there is a high level of segregation between Arabs and Jews in Israel. The Arab population is concentrated in three geo-cultural areas: the Galilee, the "Little Triangle" (both in the north of Israel), and the Negev (in the south). Most them live in separate Arab localities, and only $15 \%$ live in mixed Jewish-Arab towns and cities. Despite this, Arab-Israelis have experienced a significant process of modernization, as reflected in an increased education level (Al-Haj 2004). National statistics show that the median years of schooling among the Arab population now approximates that of the Jewish population (12 and 13 years, respectively)(CBS 2015b). This has also increased contact between Arabs and Jews, the latter of which is the reference group for socioeconomic achievements (Al-Haj 2004).

However, older Arabs have much less education and for the younger Arabs, this major advance has not been reflected in the labor market, where educated Arab-Israelis still experience difficulties finding appropriate jobs. This, in turn, perpetuates the economic disparities between Jewish and Arab citizens of Israel (Al-Haj 2004). In 2014, the average income per Arab household was 6571 New Israeli Shekels (NIS), compared to 9775 NIS for the Jewish population (CBS 2015c). In 2015, the unemployment rate of the Arab male population reached $5.2 \%$, whereas the comparative unemployment rate of the Jewish male population was $4.5 \%$. Moreover, whereas the participation of Jewish women in the labor market is $83.5 \%$, only $33.7 \%$ of Arab-Israeli women are employed (CBS 2016). Thus, although the modernization process has substantially increased the chances for socioeconomic mobility, the persistence of ethnic stratification has posed restrictions. One particular mechanism that excludes the Arab minority from senior positions is their lack of military service (they are exempt), as well as security considerations (Al-Haj 2004).
Another aspect of the Israeli context is the experience of adversity relating to the volatile security situation. Wars, military operations, and recurrent acts of terrorism are common in this region and many people are affected by their consequences, irrespective of their ethnic or cultural background (Gelkopf et al. 2008; Hobfoll et al. 2008; Johnson et al. 2009).

Four papers of the current special issue examine, in different ways, how the sub-cultured situation and the unstable security context of Israel are associated with various latelife outcomes. These papers present cutting-edge and innovative research questions in ageing that are well connected to the Israeli societal-cultural background. The paper by Dolberg and colleagues (2016) refers to the division between FSU immigrants and veteran Jewish residents of Israel (vatikim, who are Israeli-born or old-time immigrants) in the context of changes in loneliness over time. Although previous research conducted close to the time of their immigration indicated that migrants from the FSU are at risk for loneliness, the current paper by Dolberg and her colleagues emphasizes that over time, FSU migrants experienced a decline in loneliness. This might not apply to all groups of immigrants, but rather to those who represent a large, highly educated group that has extensive support (Remennick 2003).

The paper by Damri and Litwin (2016) examines the division between veteran Jewish residents of Israel, FSU immigrants and Arab-Israelis in the context of changes in late adulthood QoL. They found that engaging in work improved the QoL for FSU immigrants, but did not have a similar effect on the veteran Jewish majority or on Arab Israelis. The authors speculated that this might be related to the Soviet norms that put work at the center. The findings also indicate that Arab-Israelis have experienced a decline in QoL over time, but this has also occurred among the Jewish majority. However, the Arab group was unique in the role of family relations in predicting QoL change. Receiving or giving financial or material help, mostly within the family, alleviated the decline in QoL among the Arab-Israelis but not among Jewish subgroups (veterans and FSU immigrants). The substantiated familism-wellbeing association in the Arab-Israeli group is probably culturally bounded and is in-line with the claim that the family network has greater importance to older people from more collectivistic traditional societies than to elders who live in individualistic Western societies.

On the other hand, some similarities between the Jewish majority and the Arab minority were found in Khalaila's paper (2016) in this special section. His study explored the socio-economic and health correlates of different categories of depression (i.e., no depression, intermittent depression, and persistent depression), and found similarities in the distribution of Jews and Arabs across the 
categories. The two papers, by Damri and Litwin and by Khalaila, respectively, provide some validation for the argument, based on national data, that although there are disparities between minority and majority groups in Israel, they are actually closer to each other in terms of health and income than groups in such countries as the USA, which also has a prominent representation of minorities (Sharkansky 2004).

In this special section, Shrira and colleagues (2016) explore the health impact of adversity such as exposure to war and terrorism. More specifically, the study addresses the unique contribution of different categories of life-time traumatic events (i.e., exposure to war and terrorism, bereavement and victimization) to late-life health and functionality. The current analysis capitalized on the special adversity module available in SHARE-Israel. Growth-curve models show that exposure to adversity circumstances of war and terrorism-related events and bereavement are found to be associated with a steeper time-related increase in self-reported disability, as well as with chronic medical conditions. Moreover, clinical levels of depressive symptoms have worsened the health deterioration of older people who were exposed to bereavement or to war and terrorism.

The contribution of past experience to disability in later life is also substantiated in the fifth paper in the special section. Weinstein (2016) addresses the impact of perceived early-life SES conditions on healthy ageing. A new retrospective "mini-childhood" module, which was incorporated for the first time in the third wave of SHARE-Israel (corresponding to Wave five in SHARE in Europe), assessed the number of books in one's childhood home and perceived financial status in childhood. Weinstein found that higher childhood SES is associated with better performance on hand grip strength and chair-rise tests in midlife and late life. Her paper contributes to the growing body of research that emphasizes the implications of socio-economic status in childhood on later-life health consequences. It is also worth noting, in closing, that the above-mentioned divisions in Israeli society were treated in Shrira et al. and Weinstein's papers, respectively, as covariates. Due to the relevance of these divisions to both inquiries, it would be worthwhile to examine moderation effects in future studies.

In sum, SHARE-Israel data allow for exploration of the impact of the societal-cultural-political context of Israel on healthy ageing, as well as many other research questions with international scientific merit. There was not enough space in this brief editorial to fully portray the intricacies of the Israeli context, and the complex, dynamic nature of Israeli society (for additional reading, see Agbaria and Mustafa 2012; Eisenstadt 2008). Future waves of SHAREIsrael will help to continue to follow the changes in the multifaceted Israeli context and the associations of these changes with the ageing process.

\section{References}

Agbaria AK, Mustafa M (2012) Two states for three peoples: the 'Palestinian-Israeli' in the future vision documents of the Palestinians in Israel. Ethnic Racial Stud 35:718-736. doi:10. 1080/01419870.2011.598234

Al-Haj M (2002) Identity patterns among immigrants from the Former Soviet Union in Israel: assimilation vs. ethnic formation. Int Migr 2:49-70

Al-Haj M (2004) The status of the Palestinians in Israel: a double periphery in an ethno-national state. In: Dowty A (ed) Critical issues in Israeli society. Praeger, Westport, pp 109-126

Ben-Rafael E, Lyubansky M, Gluckner O (2006) Building a Diaspora: Russian Jews in Israel, Germany and the USA. Brill, Leiden, Boston

Ben-Rafael E, Olstein E, Geist E (1998) Perspectives of identity and language in the absorption of immigrants from the FSU. The Hebrew University of Jerusalem, The Institute for Research and Development in Education, Jerusalem

Ben-Rafael E, Sharot S (1991) Ethnicity, religion, and class in Israeli society. Cambridge University Press, Cambridge

Central Bureau of Statistics (CBS) (2015a) Population, by population group. http://www.cbs.gov.il/reader/shnaton/templ_shnaton_e. html?num_tab=st02_01\&CYear=2015. Accessed 28 Jun 2016

Central Bureau of Statistics (CBS) (2015b) Population aged 15 and over, by population group, years of schooling, age and sex. http://www.cbs.gov.il/reader/shnaton/templ_shnaton_e. html?num_tab=st08_72\&CYear=2015. Accessed 28 Jun 2016

Central Bureau of Statistics (CBS) (2015c) Paid income of employees from the 2014 Household Expenditure Survey (In Hebrew). http://www.cbs.gov.il/reader/newhodaot/hodaa_template. html hodaa $=201515276$. Accessed 28 Jun 2016

Central Bureau of Statistics (CBS) (2016) Labour force survey data, December, 4th Quarter and Annual data of 2015. http://www. cbs.gov.il/reader/newhodaot/hodaa_template_eng.html?hodaa= 201620024. Accessed 28 Jun 2016

Cohen Y, Haberfeld Y, Kogan I (2011) Who went where? Jewish immigration from the Former Soviet Union to Israel, the USA and Germany, 1990-2000. Isr Aff 17(1):7-20

Damri N, Litwin H (2016) Minority population group status and QOL change: the case of older Israelis. Eur J Ageing. doi:10.1007/ s10433-016-0396-x

Dolberg P, Shiovitz-Ezra S, Ayalon L (2016) Migration and changes in loneliness over a 4 year period: the case of older former Soviet Union immigrants in Israel. Eur J Ageing. doi:10.1007/ s10433-016-0391-2

Dowty A (2004) Introduction: the tribalization of Israel. In: Dowty A (ed) Critical issues in Israeli society. Praeger, Westport, pp 1-6

Eisenstadt SN (2008) Collective identities, public spheres, civil society and citizenship in the contemporary era-with some observations on the Israeli scene. Citizsh Stud 12:203-213. doi: 10.1080/13621020802015354

Gelkopf M, Solomon Z, Berger R, Bleich A (2008) The mental health impact of terrorism in Israel: a repeat cross-sectional study of Arabs and Jews. Acta Psychiatr Scand 117:369-380. doi:10. 1111/j.1600-0447.2008.01164.x

Gitelman Z (2004) The "Russian revolution" in Israel. In: Dowty A (ed) Critical issues in Israeli society. Praeger, Westport, pp 95-108 
Hobfoll SE, Canetti-Nisim D, Johnson RJ, Palmieri PA, Varley JD, Galea S (2008) The association of exposure, risk, and resiliency factors with PTSD among Jews and Arabs exposed to repeated acts of terrorism in Israel. J Trauma Stress 21:9-21. doi:10.1002/ jts. 20307

Horowitz T (2003) The Increasing political power of immigrants from the Former Soviet Union in Israel: from passive citizenship to active citizenship. Int migr 41(1):47-73

Johnson RJ, Canetti D, Palmieri PA, Galea S, Varley J, Hobfoll SE (2009) A prospective study of risk and resilience factors associated with posttraumatic stress symptoms and depression symptoms among Jews and Arabs exposed to repeated acts of terrorism in Israel. Psychol Trauma 4:291-311. doi:10.1037/ $\mathrm{a} 0017586$

Khalaila R (2016) Depression statuses and related predictors in later life: a 10 year follow-up study in Israel. Eur J Ageing. doi:10. 1007/s10433-016-0384-1

Kimmerling B (1998) The new Israelis: multiple cultures with no multiculturalism. Alpayim 16:264-308

Litwin H, Leshem E (2008) Late-life migration, work status, and survival: the case of older immigrants from the former Soviet Union in Israel. Int Migr Rev 42:903-925. doi:10.1111/j.17477379.2008.00152.x

Malter F, Börsch-Supan A (eds) (2015) SHARE Wave 5: innovations $\&$ methodology. MEA, Max Planck Institute for Social Law and Social Policy, Munich

Rabinowitz D (2001) The Palestinian citizens of Israel, the concept of trapped minority and the discourse of transnationalism in anthropology. Ethnic Racial Stud 24(1):64-85

Remennick L (2003) Retired and making a fresh start: older Russian immigrants discuss their adjustment in Israel. Int Migr 41:153-175
Remennick L (2006) Russian Jews on three continents: identity, integration and conflict. Transaction Publishers, New Brunswick

Sharkansky I (2004) A critical look at Israel's economic and social gaps. In: Dowty A (ed) Critical issues in Israeli society. Praeger, Westport, pp 129-150

Shrira A, Palgi Y, Bodner E, Shmotkin D (2016) Which category of lifetime adversity accelerates physical impairment among Israeli older adults? Eur J Ageing. doi:10.1007/s10433-016-0366-3

Smooha S (1994) Outline of the discussion of the impact of the mass Soviet immigration on Israeli society. Newsl Isr Sociol Assoc 13(6):7

Smooha S (1997) Ethnic democracy: Israel as an archetype. Isr Stud 2(2):198-241

Smooha S (2010) Arab Jewish relations in Israel. Washington: United States Institute for Peace. http://www-dev.usip.org/sites/default/ files/PW67_Arab-Jewish_Relations_in_Israel.pdf. Accessed 28 Jun 2016

Sokolovsky J (ed) (2009) The cultural context of aging: worldwide perspectives. Praeger, Westport

Weinstein G (2016) Childhood conditions and current physical performance among non-institutionalized individuals aged 50+ in Israel. Eur J Ageing. doi:10.1007/s10433-016-0380-5

Yiftachel O (2006) Ethnocracy: land and identity politics in Israel/ Palestine. Philadelphia University of Pennsylvania Press, Philadelphia

Yiftachel O, Ghanem A (2004) Understanding 'ethnocratic'regimes: the politics of seizing contested territories. Polit Geogr 23:647-676. doi:10.1016/j.polgeo.2004.04.003 